\title{
The Holistic Approach in Education Development Programs: Case of Indonesia Mengajar
}

\author{
Adsina Fibra', Juliana Berewot ${ }^{2}$ \\ ${ }^{1}$ Character Building Development Center, Communication Department, Faculty of \\ Computing and Media, Bina Nusantara University, Jakarta 11480, Indonesia \\ ${ }^{2}$ Character Building Development Center, Communication Department, Faculty of \\ Computing and Media, Bina Nusantara University, Jakarta 11480, Indonesia \\ Received: September $9^{\text {th }}, 2019 /$ Accepted: September $29^{\text {th }}, 2019$

\begin{abstract}
This paper aims to describe one of sustainable projects of improving education quality in archipelagic nations. Indonesia Mengajar is an Indonesian NGO based in Jakarta which promotes volunteerism by being young educators. Their projects aim to fill the shortage of primary school teachers, especially in remote areas. By sending the best Indonesian university graduates which have been intensively trained to work as teachers for one consecutive year, it was expected they will be able to inspire young people to choose careers as educators. It is a qualitative study on how the organization plans and executes their projects. The findings stimulate further questions on how to solve the issue of quality education in Indonesia.
\end{abstract}

Keywords: holistic approach, quality education, volunteerism, and teacher shortage

\section{INTRODUCTION}

The Indonesia Constitution is one of the oldest constitutions in the world that guarantees the right of education for its citizens. Although during the last 25 years Indonesia has been successful in increasing the access to primary education, the country still faces many education issues such as the gender disparity issue and the low quality of education. It is also important to keep in mind that although on the scale of $0 \%$ to $100 \%$, the rate of primary student enrollment seems high and has reached $97 \%$ in 2011, but Indonesia has a huge population which consists of 256 million people (2016), which leaves about 75 million children at school age. Media Indonesia (2011), a national newspaper, announced a shockingly high number of children who were out of school that reached 13 million. They mainly live in the rural and remote areas. The majority of rural and remote schools have a shortage of teachers. The condition has also worsened because of a high rate of teacher absenteeism. The poor quality of teacher contributes to the high number of students drop out and poor education quality (Ibrahim, 2012).

In 2010, Indonesia Mengajar (IM) sent its first batch of 50 teachers to five regencies; Tulang Bawang in Lampung, Bengkalis in Riau, Passer in Kalimantan Timur, Halmahera in North Maluku and Majene in West Sulawesi. IM is a Non-Governmental Organization which was established in Jakarta in 2009. Indonesia Mengajar was initiated by Anies Baswedan, the Rector of Paramadina University, who was named one of 2009's Young Global Leaders by the World Economic Forum (WEF). 
Indonesia Mengajar help to fill the shortage of primary school teachers, especially in remote areas by sending the best Indonesian university graduates which have been intensively trained to work as a teacher for one year. Through Gerakan Indonesia Mengajar (Indonesian Teaches), Indonesia's young and best graduates can dedicate themselves and serve the country by teaching children. After completing their teaching services, these young people can share their valuable experience in their workplace and inspire others.

Anies Baswedan mentioned the main purpose of Indonesia Mengajar is to place education as the instrument to improve people social status. It is similar with a program conducted by Indonesian Government back in 1950 named Pengiriman Tenaga Mahasiswa (PTM), a university students deployment program. During 1951- 1952, PTM had sent 1.487 students to teach in 161 high schools in 97 remote areas off Java. As a result of this PTM program, the number of high school student applied for higher education had increased, especially for those who were from lower class inspired to pursue higher education. Prior to PTM, only children of the noble and well-off families were able to get higher education (Kompas, 2010).

\section{METHODS}

This study used a qualitative descriptive research. It is an exploratory study of Indonesia Mengajar's projects through the years. Exploratory studies tend toward loose structures with the objective of discovering future research tasks (Cooper and Schindler, 2008). One of the advantages of using qualitative research is that the researcher can have many alternative sources of data. The researcher has options to use interviews, observations, videos, documents, drawings, diaries, memoirs, newspapers biographies, historical documents, and other sources not listed here (Corbin and Strauss, 2008).

Data collection in this study were mainly taken from related newspapers articles, government regulations, the World Bank's Annual Report on education in Indonesia, and other related data from the official websites such as Indonesia Mengajar's website, World Bank' s website, Central Statistical Office, and solidaritas.com. The research questions are how the Indonesia Mengajar as a nongovernmental organization plans and executes their projects, in order to improve quality of Indonesian education especially in the case of teacher shortage in remote areas.

\section{RESULTS AND DISCUSSION}

\section{The Holistic Approach}

Indonesia Mengajar believes that the society can be independent by and grow stronger, and believe that the education development in one area is determined by the educational local actors, such as teachers, parents, the regency government and the people. 


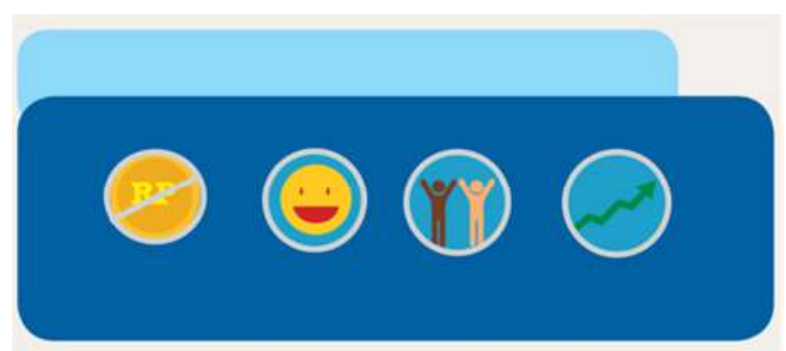

Figure 1 Indonesia Mengajar's Approach

Indonesia Mengajar chooses a holistic approach:

\section{Send people, not money or goods}

To recruit and equip the best potential young generation which has teaching passion and high initiative to create change. The young teachers (Pengajar Muda) have a duty to teach and live in with the local people in a village for one year, in addition to inspire and motivate their students and to become an agent of change for other stakeholders.

\section{Involvement of all people}

Work closely with the stakeholders as the direct partners, such as headmasters, teachers, parents, and local government (from regency to village levels)

\section{Focus on behavior change}

Focus on individual and stakeholders' behavior change as one entity and build active and positive communication.

\section{Long term work}

Employing the young teachers continuously for 5 years until there is sustainable change in the piloted elementary schools, the schools are independent without depending on one person or program support.

\section{The Young Teachers' Profiles}

When Indonesia Mengajar Program (IMP) was launched in 2010, they received amazing respond from public. There were 1.383 people registered in the recruitment of the first batch teachers, even though the requirements to be IMP teachers are very competitive such minimum 3.O GPA and age is under 25-year-old. The applicants were the best graduates of reputable higher education throughout Indonesia. After series of test, there were 160 candidate and at last only 51 best graduates selected and placed in five remote areas in Indonesia (Kompas, 2010).

One of the young teacher named Ayu Kartika Dewi. When she joined the IM, she was in her early 20 s and had a promising career at the Singapore office of the multinational firm Procter \& Gamble. She has gladly given it up to spend a year in a remote town in Sulawesi. "I don't want to look back and regret that I just went through the usual phases of going to school then work," Ayu said. "I want a chapter of my life to be filled with something meaningful, that will actually help others." Ayu is one 51 new teachers (Sagita, Jakarta Globe, 2010).

In addition, Evi Trisna, a spokeswoman for Indonesia Mengajar, said that they were looking for candidates who had a passion to teach and were committed to make a change. "Creative minds are another important thing we're looking for," she said (Rulistia, Jakarta Post, 2010).

Erwin Puspaningtyas, a forestry graduate from the Bogor Institute of Agriculture (IPB), said that she knew a little about teaching before she became a teacher in an orphanage in Bogor. "I've always 
loved children. When I was in college, I wanted to do something related to children in my free time," she said (Rulistia, Jakarta Post, 2010).

Spending a year in a remote area far from the comforts of home may sound terrible, but for some it's an exciting challenge and an effective way to improve education in the country.

Bandung Institute of Technology (ITB) graduate Bayu Adi Persada said he immediately applied when he found a vacancy for teaching job in a remote area that was posted by the non-profit organization Indonesia Mengajar (Teach Indonesia). "Education and other social problems have always been my passion, as well as traveling. That is why I didn't think twice when I heard about the vacancy," he said (Rulistia, Jakarta Post, 2010).

The level of enthusiasm of young people to join this IMP has been relatively high. From 2010 until 2015, Indonesia Mengajar has deployed 621 young teachers in 17 regencies across the country. There are currently 127 youths on duty from our batch 9th and 10th. The last batch of 2015 consists of 50 teachers who were selected from among a total of 8,249 applicants (Jakarta Post, 2015).

\section{Management and the Implementation of the Young Teachers Program}

To achieve its goals, Indonesia Mengajar manages the program with careful planning and makes process of learning as the part of organization culture. The young teachers are expected as the spear's head to achieve the expected social impacts. These are the main five activities of the Young Teachers Program:

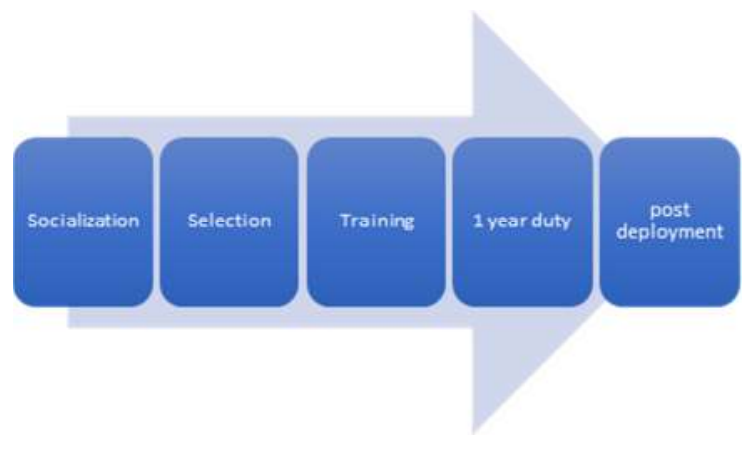

Figure 2 Project Phases

\section{Socialization}

There were 100.936 applicants graduated from 126 Indonesian and 33 foreign universities, the acceptance rate to be the Indonesia Mengajar young teacher is less than $1 \%$

\section{Selections}

There are five stages of selection: Automatic Scoring, Manual Scoring, Direct Assessment, referees Checking, Medical check-up, multi-assessors (certified) multi-tools and digital selection system.

\section{Training}

The selected young teachers follow a seven-week intensive training which focus on pedagogy and leadership. 


\section{1 Year Duty}

To mobilize the local actors, conduct monitoring and evaluation using the outcome mapping, behavior change, perform four duties holistically, in curriculum, extra curriculum, community development and local government involvement.

\section{Post deployment}

Individual and program reflection, providing individual portfolio, capacity building and networking, career planning and future education planning.

\section{Building Sustainable Regions}

Indonesia Mengajar young teachers work in one area for five years to support sustainability. They believe the importance of involvement, development, and collaboration with various stakeholders. Therefore, this organization develop its focus activity into three stages. It is expected after five years; these regions will be able to carry out the mission to develop education in their region independently even without any present of the Young Teachers.

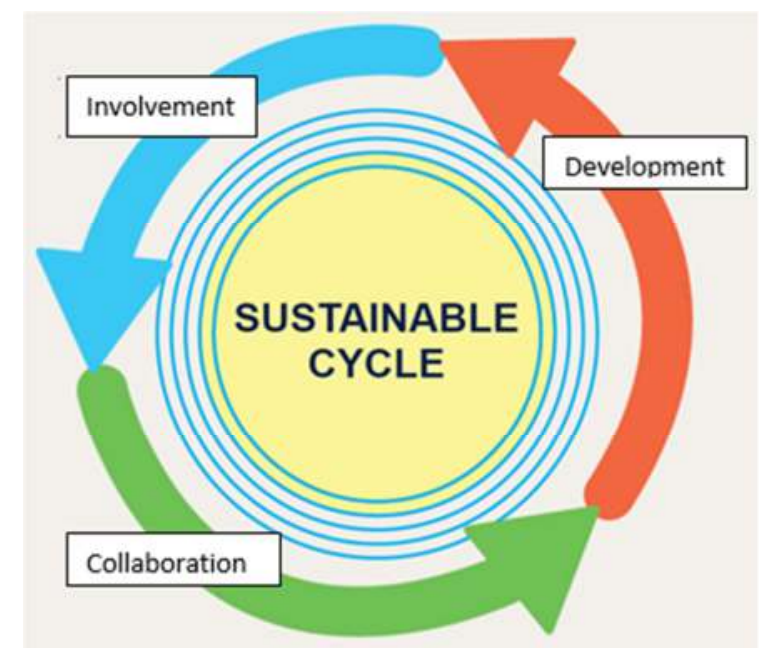

Figure 3 the Sustainable Cycle

\section{a. Stage I-Involvement}

The Young Teachers identify the local actors who are potentially to change the people in their region and get them to involve in the initiatives at the village until the regency level.

\section{b. Stage II-Development}

The Young Teachers focus in capacity development of these local actors by opening the network and encourage them to interact with communities outside their regency.

\section{c. Stage III- Collaboration}

The Young Teachers foster the collaboration between local actors and people outside their region. 


\section{The Indonesia Mengajar's Scope of Work}

In 2010, Indonesia Mengajar reached into 13 regencies and within five years it reached up 146 regencies. In five years, there are 621 young teachers and have involved 106.282 people.

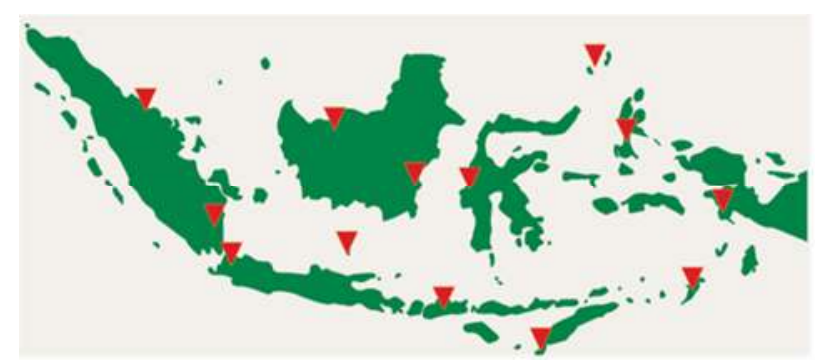

Figure 4 The Map of Activities in 2010

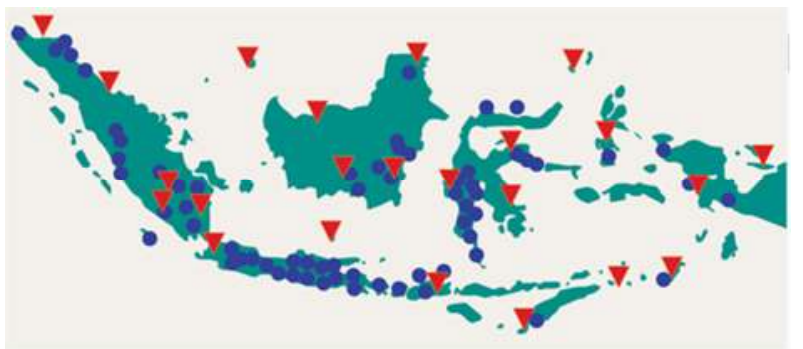

Figure 5 The Map of Activities in 2015

\section{Indonesia Mengajar's Partners}

There are organizations have contributed in actions of educating the nation. Here are the list of activities and donors:

\section{a. The Elementary School Partner (Mitra Pendamping Sekolah Dasar)}

For the last five years, PGN has consistently collaborate with IM to support 25 elementary schools in Musi-Banyuasin, Muara Enim, Tulang bawang Barat, Lebak and Gresik Regencies

Since 2012, PT Donggi-Senoro LNG consistently sypport four elementary

\section{Liquefed Natural Gas} schools in Kabupaten Banggai. PermataBank Kabupaten Majene. In 2016 supported two more schools in Kabupaten Natuna.

During 2012-2015, Bank Permata supported two elementary schools in 
Since 2012, PT Nutrifood Indonesia has supported one elementary school in Kabupaten Majene. In 2016 through Nutrisari W'Dank they support one elementary school in Kabupaten Konawe.

Dorica

Since 2014, PT Orica mining Services have supported three elementary schools in Kabupaten Paser. In 2016 adding their support to three more schools in Kabupaten Nunukan.

Since 2015, Mitsubishi Corporation has supported three elementary schools in Kabupaten Aceh Utara.

Since 2014, PT BFI Finance Indonesia Tbk has supported one elementary school in Kabupaten Paser. in 2015 adding support to two new schools in di Kabupaten Banggai.

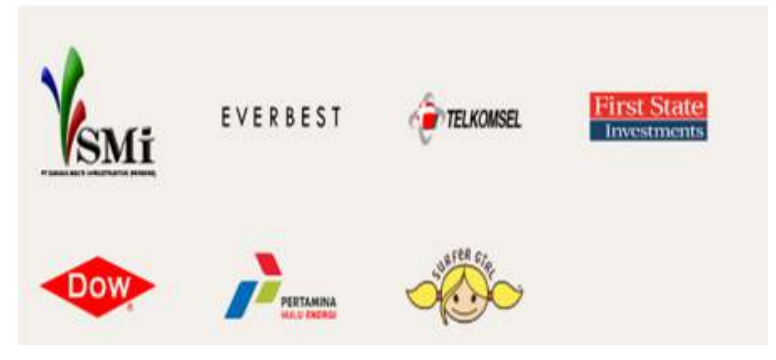

b. Fundraising Partners (Mitra Penggalang)

Since 2015, PT Ultrajaya Milk Industry \& Trading Company Tbk has collaborated with Indonesia Mengajar to get public donation through untuk mengajak Shake to Care More program.

Since 2014, PT Nusantara Compnet Integrator has supported one elementary school in Kabupaten Bima. In 2016 supoorted one elementary school in Kabupaten Nunukan.

PT Lee Cooper Indonesia supportd one elementary school in Kabupaten Nunukan. 


\section{c. Recruitment Partners (Mitra Rekrutmen)}

Since 2015, Bank BTPN has collaborated with Indonesia Mengajar to do socializationa dn recruitment of young teachers batch 13rd.

\section{d. Training Partners (Mitra Pelatihan)}

Chevron Since 2014, PT Chevron Pacific Indonesia has been training parters in the training of young teachers batch $11^{\text {th }}$. The intensive training is conducted twice a year for $7^{\text {th }}$ weeks.

Since 2012, Indosat Ooredoo has been a training partners of young teachers. The intensive training is conducted twice a year for 7th weeks, which located at the Indosat Training Center and Conference, Jatiluhur, Purwakarta.

\section{MeRCK Wardāh}

\section{e. Transportations and Logistic Partners (Mitra Transportasi dan Logistik)}

Since 2011, Garuda Indonesia through GarudaMiles program has participated to suppot Indonesia Mengajar by collecting diantion from flight loyalty point (mileage). The Garuda Indonesia collected mileage use for flight tickets to send off young teachers, before and after their teaching mission.

Since 2015, Blue Bird through Blue Bird Care Program has pupported peduli turut Indonesia Mengajar as the Official Ground Transportation Partner. Blue Bird Group

BLUE BIRD GROUP involve in providilng vehicles for trainings to predeparture transportation of young teachers.

\section{GO JEK JNE}

\section{f. Public campaign Partners (Mitra Kampanye Publik)}

KOMPAS GRAMEDIA Since May 2013, Kompas Gramedia has become the oficial partner of Indonesia Mengajar. As one ofe the leading media group in Indonesia, Kompas Gramedia has exclusively exposed the activities of Indonesia Mengajar through its artcles and advertorial. 


\section{g. Auditor Partners (Mitra Auditor)}

Since 2011, PwC Indonesia has supported Indonesia Mengajar by improving its profesionalism, accountability, and standarized accounting reports akuntabilitas. The pWC PWC is a consultanting company of 1,500 employee located in Indonesia, and they are instered in improving the education quality in Indonesia.

\section{Let's be a Volunteer!}

Beside Young Teachers Program, Indonesia Mengajar also promotes the volunteerism for all. There are five programs under the volunteers based program entitled Let's be a Volunteer (Ayo Jadi Relawan):

Table 1 Number of Volunteers

\begin{tabular}{llll}
$\begin{array}{l}\text { Inspira } \\
\text { tion } \\
\text { Classes }\end{array}$ & $\begin{array}{l}\text { Festival } \\
\text { GIM }\end{array}$ & The Brighten up Indonesia & Volunteers program \\
\hline 12.734 & 10.596 & 149 & 194
\end{tabular}

\section{a. Inspiration Classes}

These classes invite professionals to contribute in education sector. The Inspirator is the name for the volunteers in these classes; they share their story of learning, work, and their contribution as part of the nation. Since its first class was conducted on 25th April 2015, these classes have spread in over 100 cities. More than ten thousand committee members and professional volunteers involve and maintain this program.

\section{b. Festival of Indonesia Mengajar Movement}

In 2013, Festival Gerakan Indonesia Mengajar (FGIM) was held for the first time. Thousands of volunteers gathered at Ancol Beach Resort for two days. They created learning media and became learning buddies for ten of thousand elementary school students in 127 schools which is located from the eastern part to the western part of Indonesia, from Aceh to Papua.

In 2015, FGIM was held for the second time. Total FGIM has distributed 70 thousand learning media and has established network of 10 thousand registered contributors.

\section{c. Rooms for Knowledge Sharing (Ruang Berbagi Ilmu)}

This is the room for teachers' capacity building and pioneers in education. Ruang Berbagi Ilmu (RUBI) was initiated during the Festival of Indonesia Mengajar Movement in 2015 as one of activities to enhance education pioneers' capacity through trainings and coaching. Through training for trainers, RUBI invite all professionals to join as speakers, attend the local training and share knowledge to teachers and education pioneers in the regions.

\section{d. The Study Room (Ruang Belajar)}

It is the activity in documenting creative teaching method from across the nation and upload it in the learning portal on http://belajar.indonesiamengajar.org/. Up to now, there are hundreds of articles with the average of 40 thousand visitor access it each month. This portal is very useful for all teachers in Indonesia 


\section{e. The Lighten up Indonesia (Indonesia Menyala)}

This program aims to build reading behavior and turns it into culture. The Lighter is a name for volunteers of this program who live in Yogyakarta, Makassar, Lampung, Bandung, Solo, Aceh, Balikpapan and other cities.

The Lighters provide books in the area where the Young Teachers are assigned. The book collecting event is called "Pack Your Spirit" (PYS). Hundred thousand of books have been donated. In addition, there are volunteers who regularly paid the children magazine bills. The hard work of these volunteers has inspired the local people to do more too. The local people provide supports by providing the learning space, accompanying children to read, doing story telling or visiting the libraries.

\section{Teachers: A Temporary or a Lifetime Professions?}

Young Teachers Program is the main program highly promoted by Indonesia Mengajar and received well respond from the society. It is claimed as one of solutions to the fix poor teachers' quality and fills out teachers' shortage in remote areas. However, young teachers only teach for one year. Why the teaching program was designed only for a year not as a lifetime profession? The founder of Indonesia Mengajar explained it in one newspaper interview:

"People are reluctant to teach in a remote area because they are concerned about their future and about their family prospects if they have to stay there for a long time," Anies said. "But if they only have to stay for a year, they will be more interested." Anies hopes the program will give the teaching profession a new image. "I hope it will inspire people to believe that being a teacher is not only noble but also prestigious and promising," he said (Jakarta Globe, 2010).

Indonesia Mengajar also hired Solidaritas, a social enterprise that committed in assisting the development planner and facilitator institutions to find creative solutions based on accurate and reliable data and information. Based on the interview with the Jakarta Post, the national newspaper, in 2016, the Solidaritas Director, Mark Fiorello, whose company was hired to facilitate a reflection of GIM's five-year journey, has commended the Indonesia Mengajar foundation's efforts in galvanizing local students to get educated, as well as maintain their enthusiasm, while also involving local actors in the process.

"So the idea is, by bringing local actors into the circle and raising their enthusiasm, they become more aware of local problems and want to get engaged in finding local solutions," Fiorello told The Jakarta Post,. he said local initiatives had also been triggered by what had been started by the Jakarta headquarters. However, he continued, the question remains whether the enthusiasm contributes to improving the quality of education. GIM must be able to find solutions to systemic issues in the education systems that are fundamental to the government's shortcomings, he added, including teacher absences (Yosephine, Jakarta Post, 2016).

One of the requirements to become a teacher in Indonesia is to possess a bachelor's degree in education. It is a four-year study in a university. Can a seven-week training developed by Teach for Indonesia Program replace the four-year university study in pedagogy or education?

\section{Putting Priorities in National Education}

The Indonesian school system is immense and diverse. With over 50 million students and 2.6 million teachers in more than 250,000 schools, it is the third largest education system in the Asia region and the fourth largest in the world (behind only China, India and the United States) (World Bank, 2014).

The Ministry of Education's strategic plan for 2005-2009 has three main pillars: (1) Increased access to education; (2) Improved education quality; (3) Better governance of the education sector (World Bank, 2014). 
World Bank and the Indonesian Ministry of Education have been working together. The focus of efforts now is on the quality of institutions and public expenditures. Key challenges include:

- Junior secondary enrollment. Indonesia has almost universal primary enrollment but at the junior secondary level improvements are slower. Only 55 percent of children from lowincome families are enrolled in junior secondary schools.

- Student learning achievement. Indonesia continues to rank low in international standardized tests of student performance, even after taking socio-economic conditions into account. In 2003, Indonesia ranked 33 out of 45 countries in the Third International Mathematics Science Study (TIMSS). In the 2006 Program for International Student Assessment (PISA), which looks at how well 15-year-old students are prepared for life, Indonesia ranked around 50 out of 57 countries in science, reading and math.

- Allocation of spending. Despite recent increases in overall spending education, Indonesia is still under-investing in secondary education, particularly junior secondary education. At the same time, operational budgets have been squeezed due to substantial increases in salary expenditures.

\section{CONCLUSION}

What Can We Do Better? Indonesia Mengajar has initiated a big movement in education and promoting volunteerism in Indonesia. They are able to get supports from various levels and stakeholders. It is also inspired other organizations to do the same program, namely Teach for Indonesia, a community development program managed by Bina Nusantara University and BUMN (State Owned Enterprises) Teaching Program in 2016 which is managed by the Ministry of State Owned Enterprise.

It is undoubtedly the responsibility of improving education quality lay on every citizen, and people must work hand in hand with the government. However, how we can contribute in developing the nations as a citizen? Can we sustain this project (Indonesia Mengajar)? Those questions are remaining unanswered yet.

\section{REFERENCES}

Cooper, D.R and Schindler, P.S, 2008. Business Research Methods: Tenth Edition. McGraw-Hill International Edition.

Corbin, J and Strauss A., 2008. Basics of Qualitative Research 3e. Sage Publications

Yayasan Indonesia Mengajar Kirim Sarjana (2010, June 4th ). Retrieved from http://edukasi.kompas.com/read/2010/06/04/20560742/Yayasan.Indonesia.Mengajar.Kirim.S arjana

Indonesia Mengajar sends 50 young teachers to remote areas. (December17th, 2015). Retrieved from http://www.thejakartapost.com/news/2015/12/17/indonesia-mengajar-sends-50-youngteachers-remote-areas.html

Sagita, D (2010) From Boardrooms to remote balkboars for 51 intrepid teachers. Retrieved fom http://jakartaglobe.id/archive/from-boardrooms-to-remote-blackboards-for-51-intrepidteachers/ 
Rulistia, N.D (August 30th, 2010) Work as a teacher, change education in Indonesia. Retrieved from http://www.thejakartapost.com/news/2010/08/22/work-a-teacher-change-educationindonesia.html

Yosephine, L. (October 14, 2016) Young teachers fill-in education gaps across the archipelago, one year at a time. Retrieved from http://www.thejakartapost.com/news/2016/10/14/youngteachers-fill-in-education-gaps-across-the-archipelago-one-year-at-a-time.html

World Bank and Education in Indonesia (September 1st, 2014). Retrieved from http://www.worldbank.org/en/country/indonesia/brief/world-bank-and-education-inindonesia

https://indonesiamengajar.org/

http://solidaritas.com/en/\# 